\title{
Pengaruh Kecerdasan Emotional Terhadap Kinerja Karyawan PT. Mopoli Raya Kecamatan Pematang Jaya
}

\section{The Influence of Emotional Intelligence on the Performance of Employees of PT. Mopoli Raya Pematang Jaya District}

\author{
Syardiansyah \\ Program Studi Manajemen, Fakultas Ekonomi, Universitas Samudra, Indonesia \\ Diterima: Arpil 2020; Disetujui: Agustus 2020; Dipublish: Agustus 2020
}

*Coresponding Email: syardiansyah@unsam.ac.id

\begin{abstract}
Abstrak
Penelitian ini dilakukan untuk mengetahui pengaruh kecerdasan emotional terhadap kinerja karyawan PT Mopoli Raya Kecamatan Pematang Jaya. Jumlah populasi dalam penelitian ini sebanyak 345 orang karyawan. Dengan menggunakan rumus Slovin, maka jumlah responden yang diambil sebanyak 78 orang karyawan. Data pada penelitian ini diperoleh dari hasil penyebaran kuesioner kepada 78 orang karyawan di tempat kerja PT Mopoli Raya Kecamatan Pematang Jaya. Dari hasil analisis data diperoleh bahwa nilai t sig. variabel kecerdasan emosional sebesar 0,077 berbanding dengan alpha sebesar 0,05, maka terdapat pengaruh tidak signifikan kecerdasan emotional terhadap kinerja karyawan PT Mopoli Raya Kecamatan Pematang Jaya. Hasil pengujian koefisien determinasi diperoleh bahwa koefisien determinasi (R) variabel kecerdasan emosional sebesar 0,009. Artinya variabel independen hanya memiliki pengaruh sebesar 0,9\% terhadap variabel dependen.
\end{abstract}

Kata Kunci: Kecerdasan Emotional, Kinerja Karyawan

\begin{abstract}
This research was conducted to determine the effect of emotional intelligence on the performance of employees of PT Mopoli Raya, Pematang Jaya District. The population in this study were 345 employees. Using the Slovin formula, the number of respondents taken was 78 employees. The data in this study were obtained from the results of distributing questionnaires to 78 employees in the workplace of PT Mopoli Raya, Pematang Jaya District. From the results of data analysis, it was found that the value of $t$ sig. emotional intelligence variable of 0.077 compared with alpha of 0.05, there is no significant effect of emotional intelligence on the performance of employees of PT Mopoli Raya, Pematang Jaya District. The results of testing the coefficient of determination obtained that the coefficient of determination $(R)$ variable emotional intelligence of 0.009. This means that the independent variable only has an effect of $0.9 \%$ on the dependent variable.
\end{abstract}

Keywords: Emotional Intelligence, Employee Performance

How to Cite: Syardiansyah (2020). Pengaruh Kecerdasan Emotional Terhadap Kinerja Karyawan PT. Mopoli Raya Kecamatan Pematang Jaya. Journal of Education, Humaniora and Social Sciences (JEHSS). 3 (1): 8-13. 


\section{PENDAHULUAN}

Sumber daya manusia merupakan aset yang sangat penting dalam sebuah perusahaan karena hampir semua kegiatan dalam perusahaan digerakkan oleh manusia. Perusahaan selalu dituntut untuk mengelola sumber daya manusia dengan baik dan professional.Sumber daya manusia sangat penting untuk selalu dipertahankan serta dikembangkan. Namun, sumber daya manusia tidak hanya dipertahankan dan dikembangkan saja namun sangatlah penting untuk diperhatikan juga kinerjanya. Dalam menjalankan kegiatan perusahaan memiliki berbagai sumber daya yang harus dikelola. Sumber daya yang dimiliki perusahaan meliputi sumber daya finasial, fisik, manusia dan kemampuan teknologi dan sistem.

Karyawan dituntut untuk dapat bekerja secara maksimal sehingga dapat mencapai tujuan yang diharapkan guna mencapai keberhasilan. Keberhasilan suatu perusahaan dapat dicapai tidak hanya melalui faktor-faktor keunggulan yang sifatnya bernilai ekonomi, namun juga ditentukan oleh keunggulan kompetitif karyawan sebagai sumber daya manusia.Keunggulan kompetitif perusahaan dapat dicapai jika karyawan dalam sebuah perusahaan dapat bekerja sesuai dengan standar kinerja yang ada sehingga dapat mencapai tujuan perusahaan secara maksimal. Dengan kinerja karyawan yang tinggi maka akan menghasilkan produktivitas yang tinggi. Namun sebaliknya, jika karyawan memiliki kinerja yang rendah maka produktivitasnya juga rendah.

Kinerja merupakan hasil kerja yang dapat dicapai oleh seseorang atau kelompok orang dalam sebuah perusahaan, sesuai dengan wewenang dan tanggung jawab masing-masing dalam rangka mencapai tujuan organisasi bersangkutan secara resmi sesuai dengan hukum dan sesuai dengan moral maupun etika. Rivai (2013:309), menyatakan kinerja merupakan hasil kerja konkret yang dapat diamati dan dapat diukur. Evaluasi kinerja karyawan sangat penting untuk dilaksanakan. Evaluasi kinerja karyawan merupakan analisis dan interprestasi keberhasilan atau kegagalan dalam mencapai kinerja dan sekaligus sebagai suatu proses umpan balik atas kinerja dan mendorong perbaikan produktivitas dimasa mendatang.

Terdapat beberapa faktor yang mempengaruhi kinerja salah satunya yaitu sumber daya manusia. Oleh karena itu untuk meningkatkan kinerja karyawan maka hal yang perlu diperhatikan adalah kecerdasan emosional. Kecerdasan emosional adalah kemampuan seseorang mengatur kehidupan emosinya dengan intelegensi (to manage our emotional life withintelligence); menjaga keselarasan emosi dan pengungkapannya (the appropriateness of emotional and its expression) melalui keterampilan kesadaran diri, pengendalian diri, motivasi diri, empati dan keterampilan sosial (Firmansyah, 2010).

Menurut Kasmir (2016) untuk mengukur kinerja dapat dilakukan melalui faktor-faktor yang mempengaruhi kinerja, terdiri dari: 1) Kemampuan dan keahlian, merupakan kemampuan atau skill yang dimiliki seseorang dalam melakukan suatu pekerjaan. 2) Pengetahuan adalah pengetahuan tentang pekerjaan. Seseorang yang memiliki pengetahuan tentang pekerjaan secara baik akan memberikan hasil yang baik. 3) Rancangan kerja, merupakan rancangan pekerjaan yang akan memudahkan karyawan dalam mencapai tujuannya. 4) Kepribadian, yaitu kepribadian seseorang atau karakter yang dimiliki seseorang. Setiap orang memiliki kepribadian atau karakter yang berberbeda satu sama lainnya. 5) Motivasi kerja, merupakan dorongan bagi seseorang untuk melakukan pekerjaan. 6) Kepemimpinan, merupakan perilaku seorang pemimpin dalam mengatur, mengelola dan memerintah bawahannya untuk mengerjakan sesuatu tugas. 7) Gaya kepemimpinan, merupakan gaya atau sikap seseorang pemimpin dalam menghadapi atau memerintahkan bawahannya. 8) Budaya organisasi, merupakan kebiasaan-kebiasaan atau normanorma yang berlaku dan dimiliki oleh suatu organisasi atau perusahaan. 9) Kepuasan kerja, merupakan perasaan senang atau gembira atau perasaan suka seseorang sebelum dan setelah melakukan pekerjaan. 10) Lingkungan kerja, merupakan suasana atau kondisi di sekitar lokasi tempat bekerja. 11) Loyalitas, merupakan kesetiaan karyawan untuk tetap bekerja dan membela perusahaan dimana tempatnya bekerja. 12) Komitmen, merupakan kepatuhan karyawan untuk menjalankan kebijakan atau peraturan perusahaan dalam bekerja. 13) Disiplin kerja, merupakan usaha karyawan untuk menjalankan aktivitas kerjanya secara sungguh-sungguh. Dari hasil penelitian terdahulu pada Hotel the Royal didapatkan bahwa kepuasan kerja dan budaya 
organisasi memiliki pengaruh yang signifikan terhadap kinerja karyawan, sehingga semakin besar kepuasan kerja karyawan dan budaya organisasinya maka semakin tinggi kinerja karyawan yang dimiliki (Syardiansah, dkk, 2020)

Individu yang memiliki kecerdasan emosional yang lebih baik dapat menjadi lebih unggul, dapat menjadi lebih terampil dalam menenangkan dirinya dengan cepat, jarang tertular penyakit, lebih terampil dalam memusatkan perhatian, lebih baik dalam berhubungan dengan orang lain, lebih cakap dalam memahami orang lain dan untuk seorang karyawan hal tersebut diperlukan agar hasil kerja pada perusahaan maksimal. Berdasarkan hasil penelitian terdahulu yang dilakukan terdapat beberapa variabel yang dapat mempengaruhi kinerja karyawan PT. Mopoli Raya diantaranya adalah lingkungan kerja, disiplin kerja, motivasi dan kompensasi (Syardiansah, dkk, 2018; Syardiansah, dkk, 2018; Syardiansah, dkk, 2019, Mora, 2020).

PT. Mopoli Raya Kecamatan Pematang Jaya merupakan perusahaan yang bergerak dalam bidang perkebunan karet. Dalam melaksanakan pekerjaan setiap karyawan memiliki kecerdasan emosional yang dapat mendukung pekerjaan setiap harinya. Hal ini diketahui dari hasil observasi awal yaitu dengan mengunjungi PT. Mapoli Raya serta melihat keadaan perusahaan beserta karyawan yang bekerja. Selain melakukan observasi dilakukan wawancara dengan karyawan bagian sumber daya manusia di PT. Mapoli Raya untuk mendapatkan kondisi karyawan. Kemudian wawancara juga dilakukan langsung dengan karyawan mengenai kecerdasan emosional berupa pengenalan perasaan mereka ketika bekerja apakah menyenangi atau tidak menyenangi pekerjaan diketahui bahwa terdapat karyawan yang merasa senang bekerja saat menerima pendapatan tetapi pada saat pendapatan sudah habis maka mereka kurang senang terhadap pekerjaannya.

Kemudian pernyataan lain berupa kemampuan dalam melakukan pekerjaan yang diberikan, terdapat karyawan yang menyatakan mampu melaksanakan pekerjaan dengan baik dan didasari dengan perasaan dan pikiran yang membutuhkan pekerjaan. Selain itu terdapat karyawan yang dapat mengelola emosi dalam bekerja yaitu selalu sabar dalam mengerjakan setiap pekerjaan rutinnya, akan tetapi terdapat juga karyawan yang kurang dapat mengelola emosi sehingga pekerjaan yang diberikan tidak dikerjakan sebagaimana mestinya. Karyawan yang bekerja tidak hanya harus memiliki kecerdasan emosi agar kinerjanya meningkat tapi juga harus memiliki kecerdasan spiritual dalam bekerja untuk meningkatkan kinerjanya, kedua hal ini memiliki nilai penting dalam pencapaian tujuan perusahaan (Syardiansah, dkk, 2018)

Karyawan juga memiliki kesadaran diri dalam menilai kemampuan sendiri untuk melaksanakan pekerjaan yang diberikan, akan tetapi ada juga karyawan yang memiliki kemampuan tetapi ketika diberikan pekerjaan merasa tidak mampu untuk melaksanakannya sehingga harus tetap pada jenis pekerjaan yang lama. Selain itu berdasarkan pengendalian diri karyawan dapat mengendalikan diri untuk bertanggung jawab atas setiap pekerjaan yang telah dilaksanakannya, dan ada juga karyawan yang tidak dapat mengendalikan diri saat memperoleh masalah dalam pekerjaan yang dilakukan dan masalah tersebut dikembalikan kepada rekan kerja lain. Selanjutnya kecerdasan emosional berdasarkan keterampilan sosial yaitu kemahiran dalam menanggapi kehendak atasan lebih cepat sedangkan dengan rekan kerja lebih lambat.

Menurut Goleman (2015) Kecerdasan emosi merupakan kemampuan emosi yang meliputi kemampuan untuk mengendalikan diri, memiliki daya tahan ketika menghadapi suatu masalah, mampu mengendalikan impuls, memotivasi diri, mampu mengatur suasana hati, kemampuan berempati dan membina hubungan dengan orang lain. Sedangkan emosi menurut kamus bahasa inggris Oxford adalah setiap kegiatan atau pergolakan fikiran, perasaan, nafsu atau setiap keadaan mental yang hebat atau meluap-luap, emosi merujuk kepada suatu perasaan dan pikiran-pikiran khasnya, suatu keadaan biologis dan psikologis sertaserangkaian kecendrungan untuk bertindak. Emosi dapat dikelompokkan sebagai suatu rasa amarah, sedih, takut, jengkel, malu dan lain-lain.

Goleman (2015) merinci lagi aspek-aspek kecerdasan emosi secara khusus sebagai berikut: 1) Mengenali emosi diri, yaitu kemampuan individu yang berfungsi untukmemantau perasaan dari waktu ke waktu, mencermati perasaan yang muncul. Ketidakmampuan untuk mencermati perasaan yang sesungguhnya menandakan bahwa orang berada dalam kekuasaan emosi. 
Kemampuan mengenali diri sendiri meliputi kesadaran diri. 2) Mengelola emosi, yaitu kemampuan untuk menghibur diri sendiri, melepas kecemasan, kemurungan atau ketersinggungan dan akibat-akibat yang timbul karena kegagalan ketrampilan emosi dasar. Orang yang buruk kemampuan dalam ketrampilan ini akan terus menerus bernaung melawan perasaan murung, sementara mereka yang pintar akan dapat bangkit kembali jauh lebih cepat. Kemampuan mengelola emosi meliputi kemampuan penguasaan diri dan kemampuan menenangkan kembali. 3) Memotivasi diri sendiri, yaitu kemampuan untuk mengatur emosi merupakan alat untuk mencapai tujuan dan sangat penting untuk memotivasi dan menguasai diri. Orang yang memiliki keterampilan ini cenderung jauh lebih produktif dan efektif dalam upaya apapun yang dikerjakannya. Kemampuan ini didasari oleh kemampuan mengendalikan emosi, yaitu menahan diri terhadap kepuasan dan mengendalikan dorongan hati. Kemampuan ini meliputi: pengendalian dorongan hati, kekuatan berfikir positif dan optimis. 4) Mengenali emosi orang lain, kemampuan ini disebut empati, yaitu kemampuan yang bergantung pada kesadaran diri emosional, kemampuan ini merupakan ketrampilan dasar dalam bersosial. Orang empati lebih mampu menangkap sinyal-sinyal sosial tersembunyi yang mengisyaratkan apa yang dibutuhkan orang atau dikehendaki orang lain. 5) Membina hubungan. Seni membina hubungan sosial merupakan keterampilan mengelola emosi orang lain, meliputi ketrampilan sosial yang menunjang popularitas, kepemimpinan dan keberhasilan hubungan antar pribadi.

Ada beberapa faktor yang mempengaruhi kecerdasan emosi individu menurut Goleman (2015), yaitu: 1) Lingkungan keluarga. Kehidupan keluarga merupakan sekolah pertama dalam mempelajari emosi. Peran serta orang tua sangat dibutuhkan karena orang tua adalah subyek pertama yang perilakunya diidentifikasi, diinternalisasi yang pada akhirnya akan menjadi bagian dari kepribadian anak. Kecerdasan emosi ini dapat diajarkan pada saat anak masih bayi dengan contoh-contoh ekspresi. Kehidupan emosi yang dipupuk dalam keluarga sangat berguna bagi anak kelak di kemudian hari, sebagai contoh: melatih kebiasaan hidup disiplin dan bertanggung jawab, kemampuan berempati, kepedulian, dan sebagainya. Hal ini akan menjadikan anak menjadi lebih mudah untuk menangani dan menenangkan diri dalam menghadapi permasalahan, sehingga anakanak dapat berkonsentrasi dengan baik dan tidak memiliki banyak masalah tingkah laku seperti tingkah laku kasar dan negatif. 2) Lingkungan non keluarga. Dalam hal ini adalah lingkungan masyarakat dan lingkungan penduduk. Kecerdasan emosi ini berkembang sejalan dengan perkembangan fisik dan mental anak. Pembelajaran ini biasanya ditunjukkan dalam aktivitas bermain anak seperti bermain peran. Anak berperan sebagai individu di luar dirinya dengan emosi yang menyertainya sehingga anak akan mulai belajar mengerti keadaan orang lain. Pengembangan kecerdasan emosi dapat ditingkatkan melalui berbagai macam bentuk pelatihan diantaranya adalah pelatihan asertivitas, empati dan masih banyak lagi bentuk pelatihan yang lainnya.

\section{METODE PENELITIAN}

Jenis data yang digunakan dalam penelitian ini terdiri dari (Situmorang dan Lufti, 2014) : a) Data kualitatif yaitu data yang tidak berbentuk angka, data kualitatif mempunyai ciri tidak bisa dilakukan operasi matematika, seperti penambahan, pengurangan, perkalian dan dan pembagian b) Data Kuantitatif yaitu data yang berbentuk angka. Sedangkan sumber data pada digunakan dalam penelitian ini, yaitu (Situmorang dan Lufti, 2014:3) : a) Data Primer yaitu data yang dikumpulkan sendiri oleh perorangan/suatu organisasi secara langsung dari objek yang diteliti dan untuk kepentingan studi yang bersangkutan yang dapat berupa interview, observasi Data primer diperoleh dengan cara melakukan penelitian pada objek penelitian yaitu karyawan PT. Mapoli Raya dengan melakukan wawancara, observasi dan memberikan kuesioner. b) Data sekunder yaitu data yang diperoleh/dikumpulkan dan disatukan oleh studi-studi sebelumnya atau yang diterbitkan oleh berbagai instansi lain. Data sekunder diperoleh dari sumber bacaan dan di kumpulkan melalui studi kepustakaan. Adapun sampel dalam penelitian ini berjumlah 78 orang responden yang diperoleh melalui rumus Slovin (Sugiyono, 2009): 


$$
n=\frac{N}{1+N \cdot e^{2}}
$$

Dimana:

$\mathrm{n}=$ ukuran sampel

$\mathrm{N}=$ ukuran populasi (345)

$\mathrm{e}=$ persen kelonggaran ketidaktelitian karena kesalahan pengambilan sampel $(10 \%)$

Metode analisis data dalam penelitian ini adalah analisis regresi linier sederhana dengan bantuan program SPSS. Adapun pengujian hipotesis dilakukan melalui Uji secara parsial (Uji t), dilakukan untuk menguji signifikansi hubungan antara variabel X dan Y, apakah X benar-benar berpengaruh terhadap variabel Y. Dimana bentuk pengujiannya adalah $\mathrm{H} 0: \mathrm{b}=0$, terdapat pengaruh tidak signifikan dari variabel independen terhadap variabel dependen atau Ha: $\neq 0$, terdapat pengaruh signifikan dari variabel independen terhadap variabel dependen. Dengan kriteria pengambilan keputusan adalah $\mathrm{H} 0$ diterima jika tsignifikan $>\alpha 5 \%(0,05)$ atau Ha diterima jika tsignifikan $<\alpha 5 \%(0,05)$

Koefisien determinasi (R2) dari hasil regresi berganda menunjukkan seberapa besar variabel terikat bisa dijelaskan oleh variabel bebasnya (Sunyoto, 2013:79).Koefisien determinasi (R2) antara 0 (nol) dan 1 (satu). Koefisien determinasi (R2) nol variabel independen sama sekali tidak berpengaruh terhadap variabel dependen. Apabila koefisien determinasi semakin mendekati satu, maka dapat dikatakan bahwa variabel independen berpengaruh terhadap variabel dependen.

\section{HASIL DAN PEMBAHASAN}

Dari hasil penyebaran kuesioner terhadap 78 orang karyawan PT Mopoli Raya selaku responden, kemudian dilakukan pengolahan data dengan bantuan program SPSS dengan hasil sebagai berikut:

Tabel 1 Hasil Uji Regresi Linear Sederhana

\begin{tabular}{|c|c|c|c|c|c|}
\hline \multirow[t]{2}{*}{ Model } & \multicolumn{2}{|c|}{$\begin{array}{l}\text { Unstandardized } \\
\text { Coefficients }\end{array}$} & $\begin{array}{c}\text { Standardized } \\
\text { Coefficients }\end{array}$ & \multirow[t]{2}{*}{$\mathrm{t}$} & \multirow[t]{2}{*}{ Sig. } \\
\hline & $\mathrm{B}$ & $\begin{array}{l}\text { Std. } \\
\text { Error }\end{array}$ & Beta & & \\
\hline (Constant) & 3,823 & ,621 & & 6,151 & ,000 \\
\hline Kecerdasan Emosional & ,012 & ,161 &, 009 &, 077 & ,939 \\
\hline
\end{tabular}

Sumber : Data primer diolah (2019)

Dalam tabel 1 hasil uji regresi linear sederhana diproleh model regresi linier yaitu $Y=3,823$ $+0,012$ X. Dari persama ini dapat diterjemahkan bahwa konstanta sebesar 3,823 adalah nilai kinerja karyawan tanpa adanya nilai variabel kercadasan emosional dalam penelitian ini. Sedangkan nilai koefisien regresi variabel kecerdasan emosional sebesar 0,012 dan bernilai positif, dapat diartikan setiap penambahan 1 satuan nilai koefisien variabel kecerdasan emosional maka kinerja karyawan akan bertambah sebanyak 0,012 satuan. Adapun hasil uji t atau uji signifikan variabel kecerdasan emosional terhadap kinerja karyawan dapat diketahui bahwa nilai t sig. variabel kecerdasan emosional sebesar 0,077 berbanding dengan alpha sebesar 0,05. Karena nilai t sig. 0,077>0,05 maka dapat dinyatakan bahwa variabel kecerdasan emosional berpengaruh tidak signifikan terhadap kinerja karyawan PT Mopoli Raya Kecamatan Pematang Jaya.

Pada tabel 2 diperlihatkan nilai koefisien determinasi (R) variabel kecerdasan emosional sebesar 0,009. Artinya variabel independen hanya memiliki pengaruh sebesar 0,9\% terhadap variabel dependen. Sedangkan sisanya dipengaruhi oleh variabel lain seperti lingkungan kerja, disiplin kerja, motivasi kerja, kompensasi dan kecerdasan spritual (Syardiansah, dkk, 2018; Syardiansah, dkk, 2018; Syardiansah, dkk, 2018; Syardiansah, dkk, 2019).

Tabel 2 Koefisien Determinasi 


\begin{tabular}{|l|l|l|l|l|}
\hline Model & $\mathrm{R}$ & R Square & $\begin{array}{l}\text { Adjusted } \\
\text { Square }\end{array}$ & $\begin{array}{l}\text { RStd. Error of the } \\
\text { Estimate }\end{array}$ \\
\hline 1 &, $009^{\mathrm{a}}$ &, 000 &,- 013 &, 37026 \\
\hline \multicolumn{5}{c}{ Sumber: Data Primer diolah (2019) }
\end{tabular}

\section{SIMPULAN}

Berdasarkan hasil pembahasan dan analisis data dapat diambil beberapa kesimpulan bahwa dari hasil uji t diperlihatkan nilai t sig variabel kecerdasan emosional 0,077>0,05 artinya bahwa variabel kecerdasan emosional berpengaruh tidak signifikan terhadap kinerja karyawan PT Mopoli Raya Kecamatan Pematang Jaya. Dan berdasarkan hasil pengujian koefisien determinasi diperoleh bahwa koefisien determinasi (R) variabel kecerdasan emosional sebesar 0,009. Artinya variabel independen hanya memiliki pengaruh sebesar $0,9 \%$ terhadap variabel dependen.

\section{DAFTAR PUSTAKA}

Eman, Azhar, M.R. \& Yoyok, S. (2014). Pengaruh Kecerdasan Emosional terhadap Kinerja Supervisor dengan Efektivitas Komunikasi sebagai Variabel Mediasi, Jurnal Ilmu Manajemen, Vol 2, No. 4 Hal. 1666-1678.

Goleman, D. (2015). Kecerdasan Emosi, Jakarta: PT. Gramedia Pustaka Utama.

Kasmir. (2016). Manajemen Sumber Daya Manusia, Jakarta: Raja Grafindo Persada.

Mangkunegara, A.P. (2015). Manajemen Sumber Daya Manusia, Bandung: Remaja Rosda Karya.

Mora, Z., Suharyanto, A., Yahya, M., (2020). Effect of Work Safety and Work Healthy Towards Employee's Productivity in PT. Sisirau Aceh Tamiang, Budapest International Research and Critics Institute, 3(2): 753-760.

Munandar, A.S. (2008). Psikologi Industri dan Organisasi, Jakarta: UI-Press.

Notoatmodjo, S. (2011). Pengembangan Sumber Daya Manusia, Jakarta: Rineka Cipta.

Nurlaila. (2010). Manajemen Sumber Daya Manusia, Bandung: Aditama.

Risma, D. (2012). Pengaruh Kecerdasan Emosional terhadap Kinerja Karyawan, EDUCHILD, Vol.1, No.1 Hal. 86-97.

Rivai, V. \& Sagala, E.J. (2011). Manajemen Sumber Daya Manusia untuk Perusahaan, Jakarta: Rajawali Pers.

Sedarmayanti. (2012). Sumber Daya Manusia dan Produktivitas Kerja, Bandung: Mandar Maju.

Setyaningrum, R., Utami, H.N. \& Ruhan, I. (2016). Pengaruh Kecerdasan Emosional terhadap Kinerja (Studi pada Karyawan PT. Jasa Raharja Cabang Jawa Timur), Jurnal Adminsitrasi Bisnis, Vol. 36, No. 1, Hal 211-220.

Sinulingga, S. (2013). Metode Penelitian Edisi 3. Medan: USU Pres

Situmorang, S.H \& Lufti, M. (2014). Analisis Data untuk Riset Manajemen dan Bisnis, Medan: USU Press.

Sugiyono. (2012). Statistik Untuk Penelitian, Bandung: Alfabeta.

Suwatno \& Priansa, J. (2011). Manajemen SDM dalam Organisasi Publik dan Bisnis, Bandung: Alfabeta.

Syardiansah, Daud, M. N, Afriadi. (2018). Analisis Pengaruh Kecerdasan Emosional dan Kecerdasan Spritual Terhadap Kinerja Karyawan Perusahaan Daerah Air Minum Tirta Peusada. Jurnal Pendidikan Ilmuilmu Sosial, Vol. 10, No. 2, Hal. 182-188.

Syardiansah, Dewi M, Lestari I. P. (2018). Pengaruh Kompensasi dan Lingkungan Kerja Terhadap Kinerja Karyawan PT Mopoli Raya Wilayah Timur Aceh Tamiang. Jurnal Niagawan, Vol. 7, No. 3, Hal. 86-94

Syardiansah, Latief, A., Daud, M. N., Windi, Suharyanto, A. (2020). The Effect of Job Satisfaction and Organizational Culture on Employee Performance of the Royal Hotel in East Aceh District. Budapest International Research and Critics Institute Journal, Vol. 3, No. 2, Hal. 118-126

Syardiansah, Susanto, H. (2018). Pengaruh Kompensasi Terhadap Kinerja Karyawan PT Mopoli Raya Di Kecamatan Seruway. Jurnal Ilmiah Sains, Tenologi, Ekonomi, Sosial dan Budaya, Vol. 2, No. 4, Hal. 79 $-82$

Syardiansah, Utami, M. P. (2019). Pengaruh Lingkungan, Disiplin dan Motivasi Kerja Terhadap Kinerja Karyawan PT Sari Pati Di Aceh Tamiang. Jurnal Konsep Bisnis dan Manajemen, Vol. 5 No. 2, Hal. 194203.

Tridhonanto. A, (2015), Melejitkan Kecerdasan Emosi, Jakarta: Elex Media Komputindo.

Wibowo, (2014), Manajemen Kinerja, Jakarta: PT Raja Grafindo Persada 